\title{
Distribution, encounter rate and conservation status of Aquiloeurycea cafetalera (Caudata: Plethodontidae), a recently described Mexican salamander
}

\author{
José Luis Aguilar-López, Adriana Sandoval-Comte, and Eduardo Pineda \\ Red de Biología y Conservación de Vertebrados. Instituto de Ecología, A. C. (INECOL). Carretera antigua a Coatepec No. 351, \\ CP 91070 Xalapa, Veracruz, Mexico.E-mail: adriana.sandoval@inecol.mx.
}

\begin{abstract}
Distribution, encounter rate and conservation status of Aquiloeurycea cafetalera (Caudata: Plethodontidae), a recently described Mexican salamander. The knowledge of the natural history of a species, its population traits and spatial distribution are essential to evaluate its risk of extinction and proposing strategies for its conservation. For poorly studied species inhabiting regions with a high degree of habitat conversion by anthropogenic activities, it is even more urgent to obtain this information. In this study, we carried out fieldwork and database analyses to obtain information on the ecology, natural history and spatial distribution of the plethodontid salamander Aquiloeurycea cafetalera, and we evaluated its conservation status according to the IUCN and the Mexican environmental agency (SEMARNAT). We found 109 individuals in 20 of the 43 localities visited (sampling effort $=1,174$ person-hours). The salamander counts ranged from one to 21 individuals per locality and the average encounter rate was 21 salamanders per 100 personhours of surveying, within a range from 2 to 117 salamanders. The current potential distribution calculated is about $2,000 \mathrm{~km}^{2}$ and fragmented, which means less than half of its original potential distribution. Our results suggest that it is necessary to include this species in biodiversity conservation programs because only a very small portion of its spatial distribution falls within natural protected areas.
\end{abstract}

Keywords: Coffee Grove Salamander, ecology, Mexico, natural history, Neotropics.

\begin{abstract}
Resumo
Distribuição, taxa de encontro e status de conservação de Aquiloeurycea cafetalera (Caudata: Plethodontidae), uma salamandra mexicana recentemente descrita. O conhecimento da história natural de uma espécie, suas características populacionais e sua distribuição espacial são essenciais para avaliar seu risco de extinção e para propor estratégias para sua conservação. Para as espécies mal estudadas e que habitam regiões com um alto grau de conversão de habitat por atividades antropogênicas, é ainda mais urgente obter essas informações. Neste estudo, nós compilamos
\end{abstract}

Received 02 March 2017

Accepted 14 November 2017

Distributed December 2017 
informação de banco de dados juntamente com trabalho de campo para obter informações sobre a ecologia, história natural e distribuição espacial da salamandra Aquiloeurycea cafetalera, e também avaliamos seu estado de conservação de acordo com a IUCN e a Agência Ambiental Mexicana (SEMARNAT). Encontramos 109 indivíduos em 20 das 43 localidades visitadas (esforço de amostragem $=1174$ horas.pessoa). A contagem de salamandras variou de um a 21 indivíduos por localidade, e a taxa média de encontro foi de 21 salamandras por 100 horas.pessoa de levantamento, num intervalo de 2 a 117 salamandras. A atual distribuição potencial calculada é de cerca de 2000 $\mathrm{km}^{2}$ e é fragmentada, o que significa menos da metade da sua distribuição potencial original. Nossos resultados sugerem que é necessário incluir essa espécie em programas de conservação da biodiversidade, visto que somente uma pequena porção de sua distribuição espacial está incluída em áreas naturais protegidas.

Palavras-chave: ecologia, história natural, México, neotrópicos, salamandra-do-café.

\section{Introduction}

Knowing the natural history of a species, its population traits, its environmental requirements, and spatial distribution is basic for understanding the relationship between the species and its environment. This knowledge could be used as a baseline for monitoring a species under threat, to evaluate its response when the environment is changing, to estimate its risk of extinction and, if necessary, to propose strategies for conservation. These tasks are essential for species that have been known for several years, but are poorly studied or recently described species for which biological and ecological information is limited. When these species inhabit regions that are undergoing a high level of habitat conversion, these tasks become urgent.

In recent years, amphibians have drawn attention in the context of conservation because of the crisis they are facing worldwide. One in three amphibian species on the planet is threatened (Stuart et al. 2008). Of the 7,697 amphibian species described to date (Frost 2017), the International Union for the Conservation of Nature has tried to assess the risk of extinction for 6,533 species, but for 1,547 of them (i.e. $24 \%$ of the species evaluated) there is insufficient data to determine their risk, and they have been assigned to the category Data
Deficient (IUCN 2017). Also among species that remain to be evaluated, several have been described only recently and presumably there is little ecological and biological information about them.

Aquiloeurycea cafetalera (Parra-Olea, Rovito, Márquez-Valdelamar, Cruz, Murrieta-Galindo, and Wake, 2010) is a recently described salamander. Originally, this species was assigned to the genus Pseudoeurycea and has been moved to the genus Aquiloeurycea by Rovito et al. (2015) based on molecular phylogenetic analysis. This species belongs to the family Plethodontidae (Parra-Olea et al. 2010), which includes twothirds of the world's salamander species (Frost 2017). The description of A. cafetalera was based on morphological and molecular analyses of specimens from six localities, distributed in the central highlands of Veracruz, Mexico. This region faces a consistent and high degree of habitat conversion and fragmentation, particularly of cloud forest and coniferous forest (Castillo-Campos et al. 2011).

The current estimate for the central Veracruz region indicates that about $80 \%$ of its original forest cover has been lost, with a concomitant increase in the area of transformed land such as cattle pastures, coffee plantations, sugarcane crops and human settlements, among other types of land use, leaving a series of forest fragments 
of different sizes that together cover around 500 $\mathrm{km}^{2}$, mainly confined to canyons, ravines and hillsides (CONABIO 2010, Castillo-Campos et al. 2011). In fact, Aquiloeurycea cafetalera is so named because it inhabits shaded coffee plantations with adjoining forest habitat. ParraOlea et al. (2010) and Murrieta-Galindo et al. (2013) also report the presence of this species in cloud forest fragments.

Given the recent description of this amphibian species that inhabits a highly transformed region and the need for basic information about it, in this study, we carried out fieldwork and database analyses to obtain information on the ecology, natural history and spatial distribution of $A$. cafetalera, and to evaluate its conservation status. Specifically, we examine its occurrence and number of individuals recorded per sampling effort (encounter rate) in different localities, describe traits of its natural history and microhabitat use, estimate its potential distribution by modeling habitat suitability and map any overlap with the Protected Areas (PA) system. Finally, we assess its conservation status according to the IUCN and Mexican environmental agency (SEMARNAT) criteria. Our aim is to contribute to the knowledge on ecology and natural history of amphibian species with data deficient or recently described, and to provide information that supports their conservation.

\section{Materials and Methods}

\section{Area and Study Sites}

The study area is located in the mountainous region of central Veracruz $\left(19^{\circ} 40^{\prime} 56.4^{\prime \prime}\right.$ and $18^{\circ} 46^{\prime} 23.9^{\prime \prime} \mathrm{N}, 9^{\circ} 07^{\prime} 36.5^{\prime \prime}$ and 96 49'43.2" W) over an elevation range of 650 to $3,050 \mathrm{~m}$ a.s.l. This area has been studied by our group for years from both an ecological and a conservation perspective because a large number of endangered amphibian species are found there. As study sites, we selected 43 sites belonging mostly to fragments of cloud forest or coniferous forest in the study area. These fragments differ in size and in their degree of conservation (low to intermediate disturbance).

\section{Salamander Sampling}

Study sites were visited from one to three times during rainy seasons (June to November) in 2010 and 2011. During each visit we used a visual encountered survey technique (Crump and Scott 1994), in which four people searched carefully in different microhabitats such as leaf litter, fallen trunks, under rocks, on moss, in bromeliads (from ground level to a height of two meters), on herbaceous and shrub plants and on bare soil. In each visit searches lasted four hours and was divided in two shifts of two hours each one between 10:00-16:00 h (day shift) and 20:00-02:00 h (night shift). Searches in two shifts were only possible in 31 of the 43 study sites, 10 sites were sampled only during nighttime and two sites were exclusively sampled during daytime. When sites were visited more than once, we avoided sampling the same area as the previous visit. Sampling effort between sites was 16 to 48 person-hours and the total sampling effort was of 1,174 person-hours.

For each salamander caught, the microhabitat used, the time, and the coordinates of capture location were registered. After identifying and measuring the salamanders, they were released, though some were preserved in $70 \%$ alcohol as voucher specimens in the Colección de Anfibios y Reptiles del Instituto de Ecología, A. C. (CARIE).

\section{Data Analysis}

Because sampling effort was different between study sites, in order to compare number of salamanders recorded depending on the applied sampling effort, we calculated the encounter rate (ER) of salamanders for each site (and for each shift: day and night) based on the following formula: $\mathrm{ER}=100 \times$ [Total number of individuals per site/Sampling effort per site (person-hours)]. 
Estimating the Potential Distribution of Aquiloeurycea cafetalera

To estimate the potential distribution of $A$. cafetalera we used the program MaxEnt version 3.3.3a (Phillips et al. 2006). MaxEnt estimates the potential geographical distribution based on the relationship between species occurrence data and its environment, expressed as a habitat suitability value (Elith et al. 2011).

For the predictive model, we used the automatic mode and the historical localities reported in original description (Parra-Olea et al. 2010), along with the localities where we recorded A. cafetalera in this study. We selected ten bioclimatic layers (30 sec-arc resolution) from WorldClim (Hijmans et al. 2005), based on an exploratory evaluation using a Jackknife analysis to identify the bioclimatic layers that made some contribution to building the model (Table 1). For modeling we selected the logistic output format to obtain values of continuous probability between 0 and 1 . Finally, we reclassified the model as binary (presence/ absence) using the minimum training presence from the model's logistic value as cutoff threshold. In order to avoid the overprediction, we eliminated the areas with low probability of species occurrence due to geographic barriers, and areas over 2,400 $\mathrm{m}$ a.s.l. as well as vegetation types where this species has not been recorded. We defined the result of this process like original potential distribution.

To calculate the current potential distribution, we clipped the original potential distribution model to only include areas with tree cover, considering only the vegetation where the species has been recorded such as cloud forest, oak forest, oak-pine forest (both primary and secondary vegetation) and shaded coffee plantations, and removing anthropogenic habitats such as human settlements, agricultural systems, grasslands and areas without apparent vegetation. Unsuitable areas such as water bodies and shrubs were also excluded. For these analyses we used Serie III vegetation maps (INEGI 2005) and the vegetation maps for the State of Veracruz (Castillo-Campos et al. 2011). We calculated the area of each fragment of the current potential distribution and the area included in the system of government protected areas (PA) using maps of the federal, state and municipal protected areas in Mexico (CONABIO 2015, CONANP 2016).

Table 1. The bioclimatic variables used to model the potential distribution of Aquiloeurycea cafetalera and their relative contribution for the model.

\begin{tabular}{lccc}
\hline $\begin{array}{l}\text { Bioclim } \\
\text { Code }\end{array}$ & Bioclimatic variables & $\begin{array}{c}\text { Contribution for } \\
\text { the model (\%) }\end{array}$ & $\begin{array}{c}\text { Permutation importance for } \\
\text { the model (\%) }\end{array}$ \\
\hline bio_10 & Mean temperature of warmest quarter & 41.4 & 0.0 \\
bio_14 & Precipitation of driest month & 34.1 & 0.5 \\
bio_7 & Temperature annual range & 8.7 & 42.3 \\
bio_4 & Temperature seasonality & 7.0 & 4.7 \\
bio_13 & Precipitation of wettest month & 5.3 & 5.3 \\
bio_15 & Precipitation seasonality & 1.4 & 1.7 \\
bio_18 & Precipitation of warmest quarter & 1.1 & 7.1 \\
bio_19 & Precipitation of coldest quarter & 0.6 & 1.0 \\
bio_6 & Minimum temperature of coldest month & 0.4 & 37.2 \\
bio_9 & Mean temperature of driest quarter & 0.1 & 0.0 \\
\hline
\end{tabular}




\section{Conservation Status Assessment}

We evaluated the conservation status of the species and assigned an extinction risk category by applying the Red List Criteria proposed by the International Union for Conservation of Nature (IUCN 2012a, b) and the Method for Assessing the Extinction Risk of Wildlife of Mexico (MER) proposed by the Mexican Ministry of Environment and Natural Resources (Sánchez et al. 2007).

The criteria used by the IUCN (2012a) to determine the extinction risk category include: population size reduction (criterion A), geographic range in the form of either extent of occurrence or area of occupancy (criterion B), small population size and decline (criterion C), very small or restricted population (criterion D), and quantitative analysis of the probability of extinction in the wild (criterion E).

There are four MER criteria and as a measure of their magnitude or intensity, each is allocated 1 to 4 points. These are added to determine whether the species is endangered and under what category. The criteria used are: distribution breadth of the taxon in Mexico (criterion A), habitat status with respect to the natural development of the taxon (criterion B), intrinsic biological vulnerability of the taxon (criterion C), and impact of human activity on the taxon (criterion D).

\section{Results}

\section{Records and Encounter Rate}

We recorded a total of 109 individuals of $A$. cafetalera at 20 of the 43 sites visited, after 1,174 person-hours of sampling effort. The altitudinal range of sites where we found this salamander was between 1,250 and $2,220 \mathrm{~m}$ a.s.l. most of them belong to cloud forest although some of them are pine and oak forest.

An average of seven individuals were recorded where this species occurred and in a range of one to 21 . The average encounter rate
(ER) during this study was 21 salamanders per 100 person-hours of surveying within a range from 2 to 117 . The $82 \%$ ( 88 individuals) of the salamanders were recorded active during the night sampling effort, while $18 \%$ (19 individuals) were recorded inactive during the daytime. Despite the night sampling effort at sites S9 and S10, no individuals were recorded, as well as during the diurnal sampling effort on the sites S3, S7 and S12 salamanders were not recorded (Figure 1).

\section{Ecological Data and Natural History}

We recorded microhabitat data for 60 salamanders, $73 \%$ of the salamanders in terrestrial microhabitats (leaf litter, bare soil, and fallen bromeliads) and $27 \%$ in microhabitats between 10 and $120 \mathrm{~cm}$ above the ground on plants. Leaf litter was the microhabitat where $A$. cafetalera was found most often with $58 \%$ of all individuals observed, followed by herbs and ferns (27\%), bromeliads (8\%) and $\operatorname{logs}(7 \%)$ (Figures 2 and 3).

Regarding reproduction, we collected two females in September 2010 (CARIE-1061 and CARIE-1080) that had two rows of ovarian eggs, one on each side along the belly, and each row had between 18 and 31 milky white eggs with a diameter of 0.99-2.42 mm. In July 2011 during fieldwork, we observed a female (alive) with a clutch of 15 eggs under a decomposing log (Figure 2B). In several sites, we also found young individuals with an overall length of less than $32 \mathrm{~mm}$ between September and November 2010 and 2011.

With respect to the coloration of A. cafetalera in life, most had dark chocolate brown dorsal coloration and the venter was dark brown with very small grey flecks, similar to the individuals described by Parra-Olea et al. (2010) (Figure 4A, B). Some specimens varied from this coloration pattern, and were reddish brown on the dorsum, with the head slightly lighter in color, the insertion of hind limbs and the last part of the tail lighter than the rest of the body 


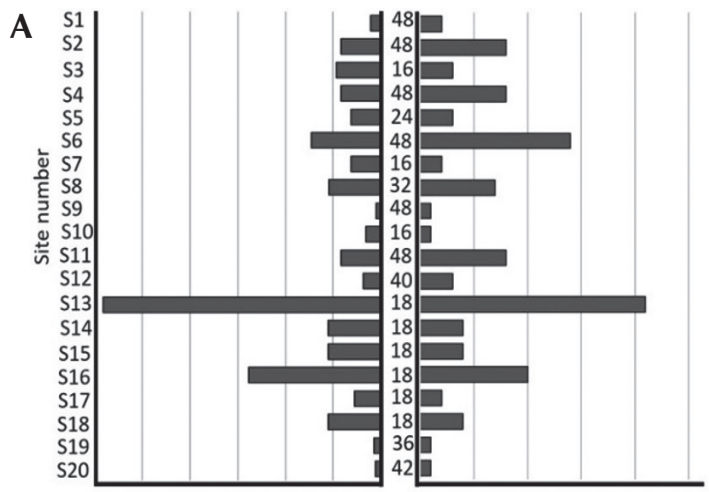

B
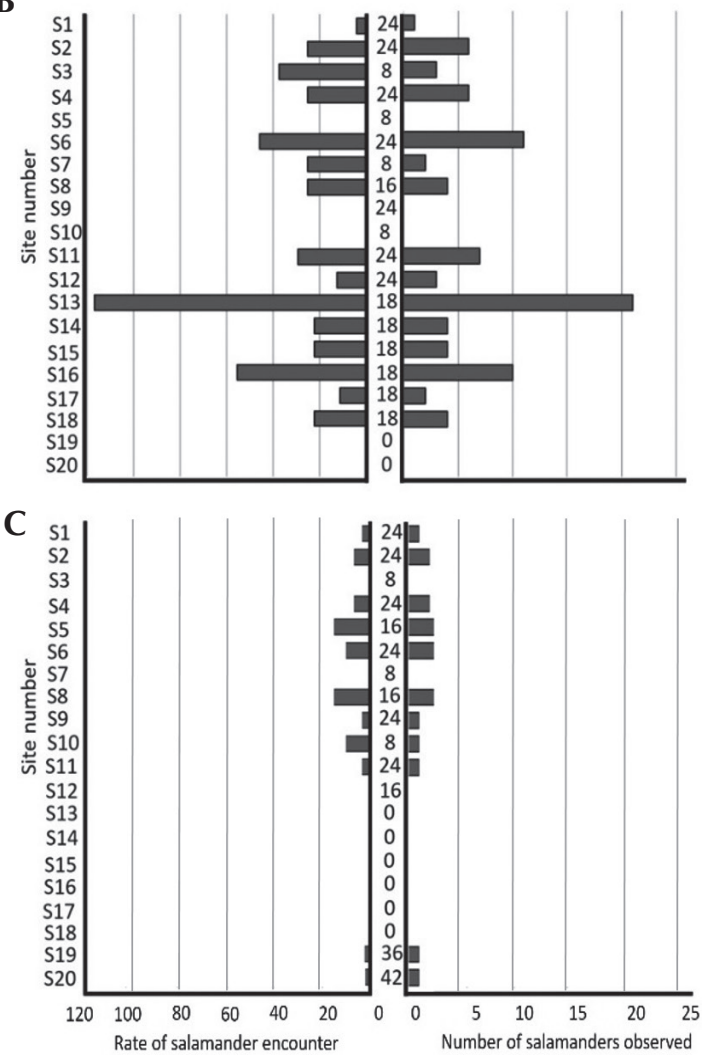

Figure 1. Encounter rate (left) and number of salamander observed (right) of Aquiloeurycea cafetalera in 20 study sites (where the species was found) and the sampling effort expressed in personhours (center) per site for all data obtained in this study (A). Separated data per sampling shift, only considering effort and salamanders observed during the night (B) and during day $(\mathbf{C})$. with gray spots at the base of the tail (Figure 4C). In some individuals, the body sides had a light gray stripe, starting at the head from under the eye and around the mouth, and extending to the intercostal region where the gray strip covered most of the side of the body, except where there was an irregular dark chocolate brown fringe, also with brown specks in the middle area of the tail (Figure 4D). The usual ventral coloration is dark chocolate brown (Figure 4E). Variation in ventral coloration included individuals with a mostly gray gular region and a dark chocolate brown venter with abundant irregular patches of light gray from the insertion of the forelimbs to the tip of the tail, including the hind limbs and the underside of the feet (Figure 4F).

\section{Potential Distribution Modeling}

The potential distribution model was developed initially using 28 locations distributed between 1,200 and 2,210 $\mathrm{m}$ a.s.l. Six locations were historical (Parra-Olea et al. 2010), 20 were new sites detected in this study and two were not visited in this study but were recorded by our group during other studies. Ten bioclimatic variables were used to develop the model (Table 1) and a threshold value of 0.108 was set.

The binary model predicts a potential distribution area of $4,574 \mathrm{~km}^{2}$. The predicted distribution is located mostly in the center of Veracruz (> 80\%) and extends discontinuously to the north along the Sierra Norte de Puebla (Cuetzalan) to Hidalgo and to the south to Oaxaca. After eliminating geographic areas with low probability of species occurrence, as Hidalgo and Oaxaca, and the highlands of Pico de Orizaba and Perote (over 2,400 m of altitude) as well as vegetation types where the species has not been recorded (coniferous forest and tropical rainforest), we estimated an original potential distribution of $3,397 \mathrm{~km}^{2}$ in an elevation range from 600 to 2,400 m a.s.l. (Figure 5A). Finally, after removing anthropogenic habitats from the original model, the current potential distribution 

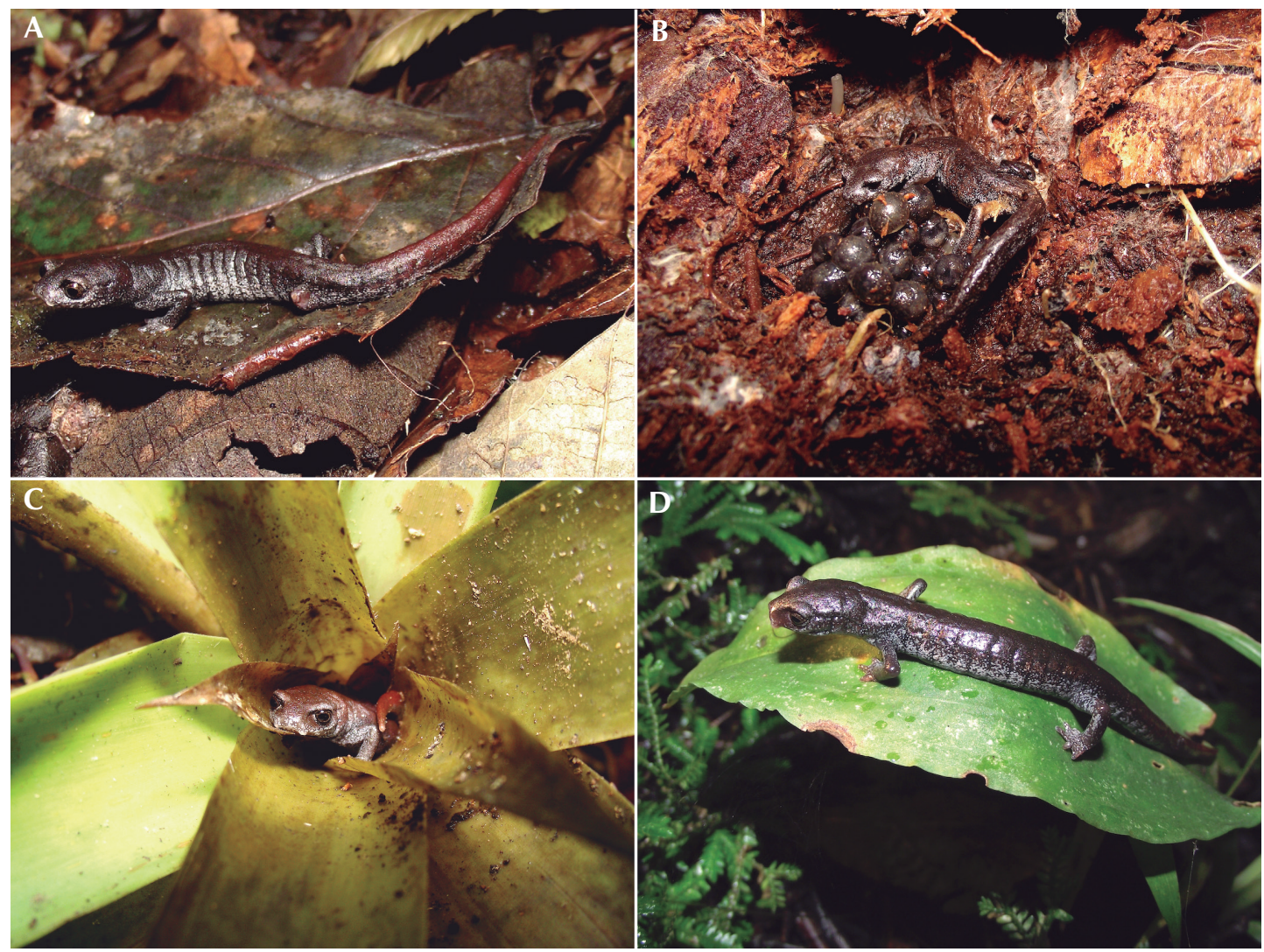

Figure 2. Some of the microhabitats used by Aquiloeurycea cafetalera: An adult on leaf litter (A); a female guarding its eggs, found it under a decomposing log (B); a male inside a bromeliad (C) and a male above an herb (D). Photos by JLAL and ASC.

was about $1,334 \mathrm{~km}^{2}$, around $61 \%$ less than the first estimation, mainly due to habitat lost by agriculture (50\%) and by urban growth (11\%).

The final model (current potential distribution) shows a highly fragmented distribution composed of 134 habitat fragments; 59 fragments are less than $1 \mathrm{~km}^{2}$ in size, 53 fragments are 1 to $10 \mathrm{~km}^{2}, 20$ fragments are 10 to $100 \mathrm{~km}^{2}$ and only two fragments are bigger than $100 \mathrm{~km}^{2}$. The highest proportion of predicted area by the model $(84 \%)$ is constituted by few fragments (22 fragments), which are bigger than $10 \mathrm{~km}^{2}$ (Figure $5 \mathrm{~B}$, Table 2). The area of the current model is mostly covered by primary vegetation (56\%), composed mainly of cloud forest (97\%), oak forest (2\%) and oak-pine forest (1\%). The model indicates that the rest of the area $(44 \%)$ is covered by secondary vegetation and shaded coffee plantations. The current potential distribution of $A$. cafetalera estimates that the species occurs within six PAs (five state level and one federal level) and in the proximity of other nine PAs (Figure 5B).

\section{Conservation Status Assessment}

The extinction risk category of A. cafetalera according to the criteria used by the IUCN is 
Vulnerable (Vu B2ab (iii)), because its area of occupancy is estimated to be less than 2,000 $\mathrm{km}^{2}$. Our potential distribution model estimated a distribution area of $1,334 \mathrm{~km}^{2}$, but we only detected occurrence in $47 \%$ of the localities sampled. Additionally, its distribution is severely fragmented and continues to decrease due to a reduction of the area and quality of the forested habitats where it lives.

According to the criteria used by MER, the extinction risk category of $A$. cafetalera is Threatened, as it scored a total of 10 points for the four criteria used. For criterion A (distribution amplitude of the taxon in Mexico), the potential distribution of this species is equal to $0.07 \%$ of the Mexican territory, resulting in a score of 4 points, i.e. very restricted distribution. For criterion B (habitat status with respect to the natural development of the taxon), the distribution appears limiting the species, in fact during fieldwork, A. cafetalera was not recorded in environments with no canopy cover, resulting in a score of 2 points, i.e. intermediate or limiting. For criterion $\mathrm{C}$ (intrinsic biological vulnerability of the taxon), the isolation of the populations restricted to patches can reduce its genetic variability, therefore we gave a score of 2 points, i.e. intermediate vulnerability. Finally, for criterion D (impact of human activity on the taxon), we considered the indirect effect of the extraction of $\operatorname{logs}$ to be used as firewood, extraction of leaf litter to be used as natural fertilizer and extraction of bromeliads to be used as ornaments in traditional ceremonies. In spite of the tolerance to the modification of their habitat, the three previous elements of the forest (logs, litter and bromeliads) represent the most important microhabitats for A. cafetalera, so we assigned a score of 2 , i.e. moderate impact.

\section{Discussion}

Our results suggest that A. cafetalera is a relatively common species because it was observed in almost half of the sampled localities in an elevational range between 1,250 and 2,220 $\mathrm{m}$ a.s.l. This salamander species lives within forested areas (mainly cloud forest), both preserved and with intermediate disturbance, and even in agroecosystems like shaded coffee plantations. Although it can tolerate moderate disturbance, the extent of its spatial distribution seems to have been reduced by more than half

Table 2. Model composition number and fragment size and contribution of habitat fragments to the model.

\begin{tabular}{lcc}
$\begin{array}{l}\text { Fragment } \\
\text { size }\end{array}$ & $\begin{array}{c}\text { Number of } \\
\text { fragments }\end{array}$ & $\begin{array}{c}\text { Total area }\left(\mathbf{k m}^{2}\right) \text { and } \\
\text { model contribution (\%) }\end{array}$ \\
\hline$\leq 1$ & 59 & $22.7(2)$ \\
$>1-10$ & 53 & $200.5(15)$ \\
$<10-100$ & 20 & $541.4(41)$ \\
$>100$ & 2 & $569.6(43)$ \\
\hline Total & $\mathbf{1 3 4}$ & $\mathbf{1 3 4 4 . 2}$ \\
\hline
\end{tabular}

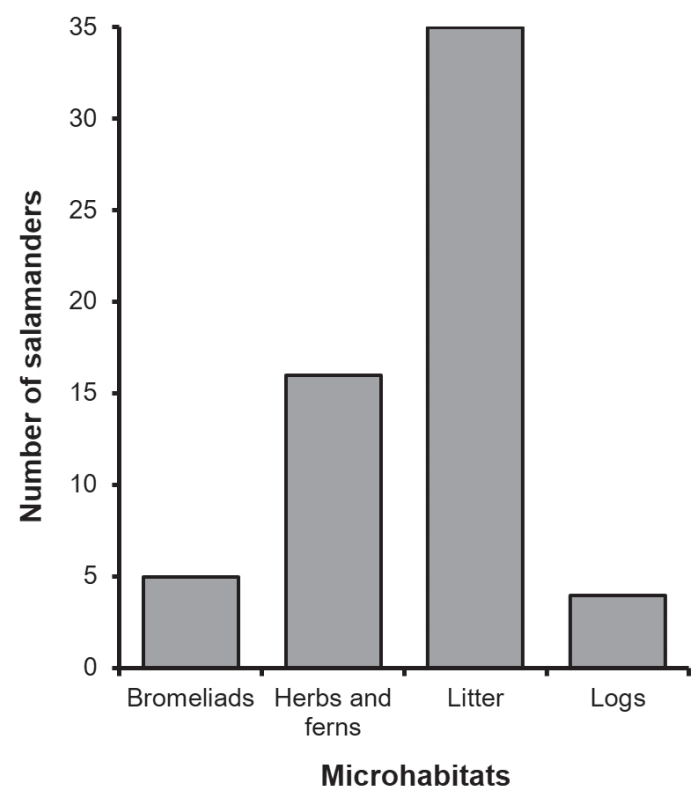

Figure 3. Total of salamanders observed per microhabitat. 


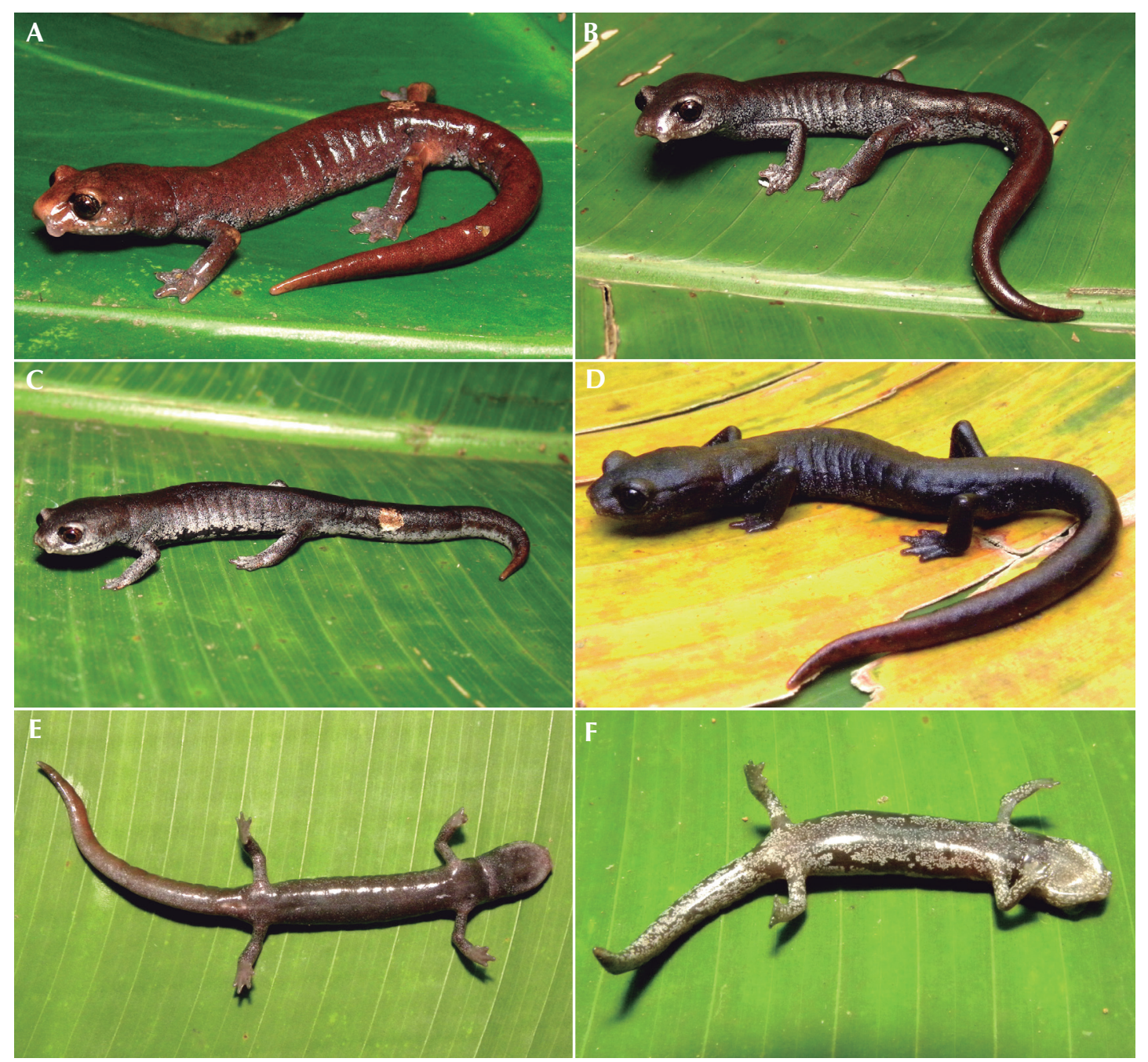

Figure 4. Variation in dorsal (A-D) and ventral color pattern (E-F) in Aquiloeurycea cafetalera. Photos by JLAL.

and is now fragmented due to habitat loss. A. cafetalera is reproductively active during the rainy season and although it is mainly found in leaf litter, it also occupies a variety of microhabitats in the forests. Using either the criteria proposed by the IUCN or those of the Mexican government to assess the risk of extinction of a species, A. cafetalera turns out a threatened species. Based on our information, it can be categorized as Vulnerable (according to IUCN) or Threatened (according to the Mexican government). Thus, it is necessary to include the species in biodiversity conservation programs, especially those developed for the amphibian fauna because a very small portion of its spatial distribution falls within natural protected areas.

Because A. cafetalera was only recently described, there are no historical data on its 

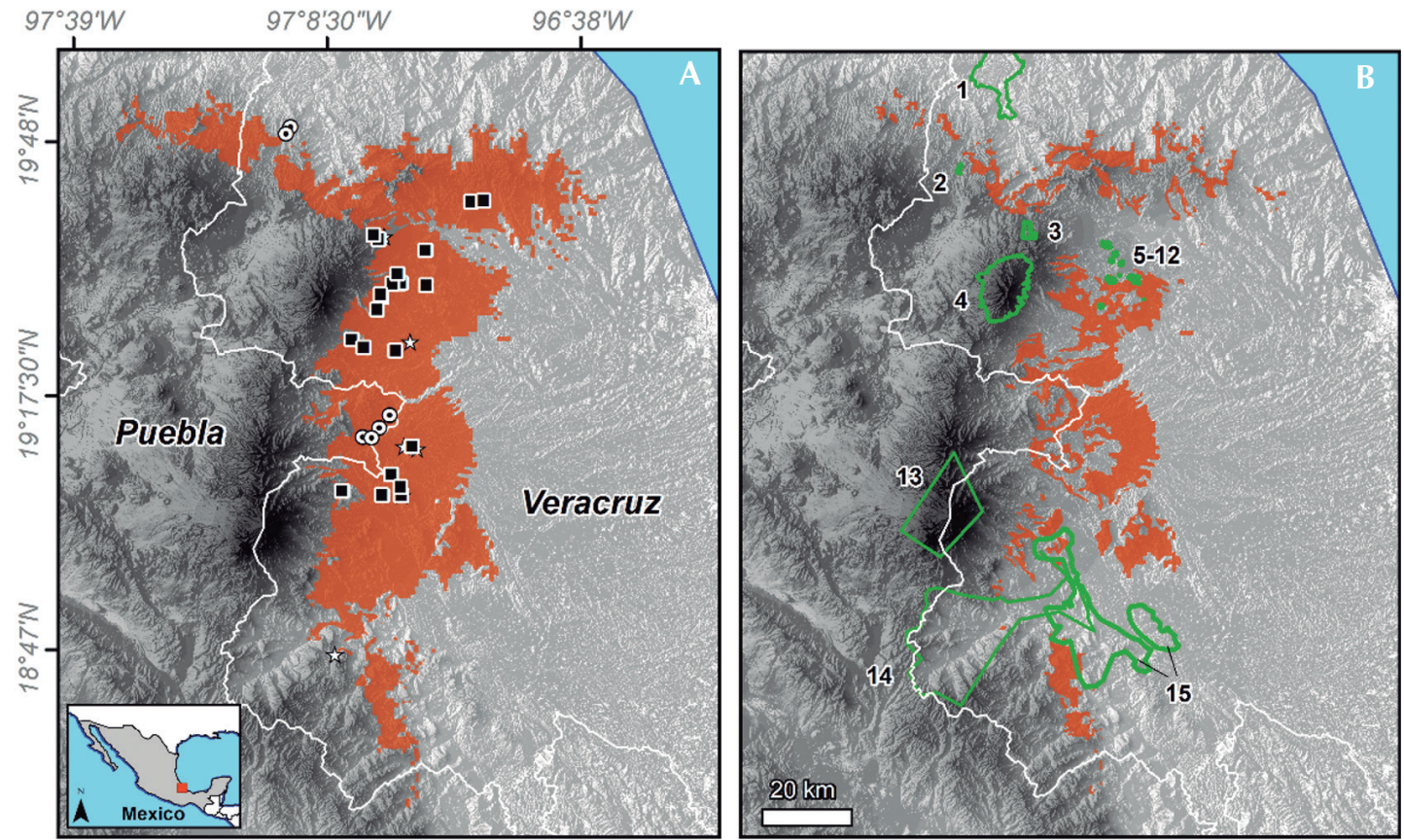

Figure 5. Original potential distribution of Aquiloeurycea cafetalera (orange area) and records of the species (A). The stars represent historic localities (Parra-Olea et al. 2010), the black boxes represent the sites where the species was sighted in this study and the white circles represent some of the localities that validated the model distribution. Current potential distribution area of $A$. cafetalera and its overlap with Protected Areas, that are represented by green polygons (B): 1) Filobobos, 2) Pancho Poza, 3) San Juan del Monte, 4) Cofre de Perote, 5) Calle Barragán, 6) Cerro de la Galaxia, 7) Cerro de las Culebras, 8) Cerro Macuiltepetl, 9) El Tejar Garnica, 10) La Martinica, 11) Molino San Roque, 12) Francisco Javier Clavijero, 13) Pico de Orizaba, 14) Cañón de Río Blanco and 15) Metlac-Río Blanco.

abundance and it is not possible to accurately assess its population trends over time. Our results on the variation of encounter rates among sites could be related to differences in abundance of salamanders between sites, but could also be a result of differences in detectability of individuals between sites (MacKenzie et al. 2003, Ficetola 2015). Variation in detection of salamanders may be associated with differences in habitat heterogeneity, climatic conditions during sampling, patterns of activity of individuals or others specific variables that influence observation of amphibians in the tropics (Rödel and Ernst 2004). This species was found active during night, recording the highest encounter rate in almost all sites in this shift, which coincides with that recorded for many tropical amphibians (Bennett 1999, Rödel and Ernst 2004). For further studies, an occupancy approach and an estimation of detection probabilities could be useful to have a more precise idea about abundance patterns and its population trends over time (Mackenzie et al. 2003).

For A. cafetalera, it seems that its presence in shaded coffee plantations is related to environmental variables such as the epiphytes density, the height, basal area and number of trees, the proportion of native tree species, canopy cover and the vertical distribution of trees in the canopy (Murrieta-Galindo et al. 2013). Our 
findings suggest that leaf litter is also an important factor for A. cafetalera because most of the salamanders we found were detected in this microhabitat. It is recognized that this species has terrestrial habits (Parra-Olea et al. 2010) and our findings show that $A$. cafetalera also occupies other microhabitats in the forests, such as shrubs and the lower parts of trees. This suggests that this species uses a variety of microhabitats within the forest to carry out its activities.

Regarding A. cafetalera reproduction data, our observations add information about its natural history that until now it was unknown for this species. Compared to other salamanders (geographically and phylogenetically closer) species, the clutch size of $A$. cafetalera is relative smaller (15 eggs) than reported for A. cephalica with a range of 22 to 28 eggs (Pavón-Vázquez et al. 2015) or Pseudoeurycea nigromaculata with records between 19 and 25 eggs per clutch (McDiarmid and Worthington 1970). Added to this, the presence of females with ovarian eggs and young individuals at several sites and at several months during this study may suggest a continuous reproduction period and a dynamic structure in its populations.

Variations in the color pattern of A. cafetalera registered in this study indicate that its color varies more than originally reported in its description (Parra-Olea et al. 2010). Further studies that explore the causes and implications of this variation are necessary, because the coloration in salamanders could be determinate by many factors including temperature, background color, radiation (García et al. 2003) and can be related to different aspects of the natural history of amphibians, such as predation (Storfer et al. 1999) or reproductive success (Ogilvy et al. 2012).

The potential distribution of A. cafetalera estimated in this study indicates a discontinuous area from northeast Puebla through the center of Veracruz, where around $80 \%$ of the estimated distribution is in its mountains. The area of the current potential distribution could be underestimated because our estimation is based on a scale of 1: 250,000 where fragments smaller than or equal to $1 \mathrm{~km}^{2}$ were automatically deleted.

After the potential distribution model was generated, we found the species in two localities near the town of Atzalan, at the northern limit of the central portion of its distribution in Veracruz, according to the model. SolanoZavaleta et al. (2013) also recorded the species for the first time in the state of Puebla, in the Chichiquila municipality at the state border with Veracruz, coinciding with the prediction of occurrence of the species. However, it is important to conduct fieldwork to assess the model and to know more accurately the real distribution of A. cafetalera.

The highly fragmented spatial distribution estimated for A. cafetalera, due to habitat loss, could present a conservation problem for the species. Habitat loss and fragmentation are considered among the largest threats to amphibians as they negatively affect the population size and population connectivity of a large number of species in this group, and can eventually increase the risk of local extinction (Cushman 2006, Johansson et al. 2007, Dixo et al. 2009). Ford et al. (2002) found a positive correlation between habitat fragment size and richness and abundance for seven salamander species, and highlighted the importance of determining the minimum area required for maintaining populations of rare or endangered species in the long term. The smallest forest fragment in this study was slightly larger than two hectares, and we do not know if this is sufficient to maintain a population in the long term, but it seems to offer suitable conditions for maintaining a population, at least in the short term.

Aquiloeurycea cafetalera seems to be a threatened species and our results indicate that there is a low coincidence of its spatial distribution with the system of natural protected areas of the region (just 6 PAs), suggesting the necessity to increase the number of protected areas. Another conservation strategy for $A$. 
cafetalera, could be the promotion of management and restoration of the humanmodified tropical landscapes in its distribution area, including landscape components like secondary vegetation (equivalent to $44 \%$ of extension area of the current potential model), where this species have been recorded and that can preserve a significant part of amphibian species of mature forests (Basham et al. 2016). In the same way, some of the fragments we studied were riparian forest remnants (forest fragments running alongside a river), which could serve as connectors between populations living in forest fragments of different sizes, as suggested by de Lima and Gascon (1999). Finally, because A. cafetalera may inhabit shaded coffee plantations (Parra-Olea et al. 2010, Murrieta-Galindo et al. 2013), this type of agroecosystem could also be used to connect populations across the landscape.

Habitat loss is the major threat to amphibians and this seems to be also the case of A. cafetalera. However, it is necessary to evaluate the impact of other potential threats such as chytrid fungus, which has been detected in the study region since the early 1970s (Cheng et al. 2011, Van Rooij et al. 2011, Murrieta-Galindo et al. 2014), though it has not yet been recorded in this species (Mendoza-Almeralla et al. 2015). In addition, organochlorine pesticides widely used in the study region (e.g. in cattle pasture and coffee plantations), can pose a major threat to this species. These compounds have been detected in some anuran species inhabiting riverine forests immersed in agriculture and pasture lands, in the study region (Valdespino et al. 2015); therefore its presence and effect on $A$. cafetalera must be evaluated.

\section{Acknowledgments}

We thank Flor Vázquez, Luis Carrillo, Antonio Vázquez, Policarpo Ronzón, Ricardo Luría, and Marco Oropeza for their invaluable help in the field, and Cecilia Tobar and Ruth
Reyna for providing occurrence data. We are grateful to the owners of the private and communal properties for their hospitality and permission to work on their land. This study was funded by CONABIO (project JF-212). Permits for this study were issued by the Mexican Wildlife Agency, Dirección General de Vida Silvestre of the Secretaría de Medio Ambiente y Recursos Naturales (collecting permit numbers: SGPA/DGVS/03665/06 and SGPA/ DGVS/03444/15). Comments and suggestions made during an academic meeting supported by the Dirección General of INECOL (project 20029-60801) improved a first version of this manuscript. We thank Milton H. Toribio, Bianca Delfosse and Bruno Bourget, that revised the English of the manuscript and we thank Wesley Dáttilo and Reuber Antoniazzi Jr. for their help translating into Portuguese part of this paper. Finally, we would like to thank the editor and reviewers for their helpful remarks.

\section{References}

Basham, E. W., P. González del Pliego, A. R. Acosta-Galvis, P. Woodcock, C. A. Medina-Uribe, T. Haugaasen, J. J. Gilroy, and D. P. Edwards. 2016. Quantifying carbon and amphibian co-benefits from secondary forest regeneration in the Tropical Andes. Animal Conservation 19: $548-560$.

Bennett, D. 1999. Expedition Field Techniques - reptiles and amphibians. United Kingdom. Royal Geographical Society, London. 94 pp.

Castillo-Campos, G., S. Avendaño-Reyes, and M. E. MedinaAbreo. 2011. Diversidad de Ambientes: Ambientes Terrestres: Flora y vegetación. Pp.163-179 in $L a$ Biodiversidad en Veracruz: estudio de estado. Comisión Nacional para el Conocimiento y Uso de la Biodiversidad, Gobierno del Estado de Veracruz, Universidad Veracruzana, Instituto de Ecología A. C. México.

Cheng, T. L., S. M. Rovito, D. B. Wake, and V. T. Vredenburg. 2011. Coincident mass extirpation of neotropical amphibians with the emergence of the infectious fungal pathogen Batrachochytrium dendrobatidis. Proceedings of the National Academy of Sciences of the United States of America 108: 9502-9057. 
CONABIO (Comisión Nacional para el Conocimiento y Uso de la Biodiversidad). 2010. El Bosque Mesófilo de Montaña en México: Amenazas y Oportunidades para su Conservación y Manejo Sostenible. Comisión Nacional para el Conocimiento y Uso de la Biodiversidad, México. 197 pp.

CONABIO (Comisión Nacional para el Conocimiento y Uso de la Biodiversidad). 2015. Áreas Naturales Protegidas Estatales, Municipales, Ejidales y Privadas de México 2015. México. Available at http://www.conabio.gob.mx/ informacion/gis/. Downloaded 19 May, 2016.

CONANP (Comisión Nacional de Áreas Naturales Protegidas). 2016. Áreas Naturales Protegidas Federales de la República Mexicana. 2016. México. Available at http://www.conabio.gob.mx/informacion/gis/. Captured on 19 May 2016.

Crump, M. L. and N. J. Scott, Jr. 1994. Visual Encounter Surveys. Pp. 84-92 in W. R. Heyer, M. A. Donnelly, R. A. McDiarmid, L.-A. C. Hayek, and M. S. Foster (eds.), Measuring and Monitoring Biological Diversity: Standard Methods for Amphibians. Washington D.C. Smithsonian Institution Press.

Cushman, S. A. 2006. Effects of habitat loss and fragmentation on amphibians: A review and prospectus. Biological Conservation 128: 231-240.

de Lima, M. G. and C. Gascon. 1999. The conservation value of linear forest remnants in central Amazonia. Biological Conservation 91: 241-247.

Dixo, M., J. P. Metzger, J. S. Morgante, and K. R. Zamudio. 2009. Habitat fragmentation reduces genetic diversity and connectivity among toad populations in the Brazilian Atlantic Coastal Forest. Biological Conservation 142: $1560-1569$.

Elith, J., S. J. Phillips, T. Hastie, M. Dudík, Y. E. Chee, and C. J. Yates. 2011. A statistical explanation of MaxEnt for ecologists. Diversity and Distributions 17: 43-57.

Ficetola, G. F. 2015. Habitat conservation research for amphibians: methodological improvements and thematic shifts. Biodiversity and Conservation 24: 1293-1310.

Ford, W. M., M. A. Menzel, and R. H. Odom. 2002. Elevation, aspect, and cove size effects on southern Appalachian salamanders. Southeastern Naturalist 1: 315-324.

Frost, D. R. (ed.). 2017. Amphibian Species of the World: an Online Reference. Version 6.0. Electronic database accessible at http://research.amnh.org/herpetology/ amphibia/index.html. New York, USA (American Museum of Natural History). Captured on 5 August 2017.
Garcia, T. S., R. Straus, and A. Sih. 2003. Temperature and ontogenetic effects on color change in the larval salamander species Ambystoma barbouri and Ambystoma texanum. Canadian Journal of Zoology 81: 710-715.

Hijmans, R. J., Cameron, S. and J. Parra. 2005. WorldClim Version 1.3. University California, Berkley, CA. http:// biogeo.berkeley.edu/worldclim/worldclim.html. Captured on 03 September 2014.

INEGI (Instituto Nacional de Estadística y Geografía). 2005. Conjunto de Datos Vectoriales de la Carta de Uso del Suelo y Vegetación, Escala 1:250,000, Serie III, Continuo Nacional. Available at http://www.conabio. gob.mx/informacion/gis/. Captured on 03 September 2014.

IUCN. 2012a. IUCN Red List Categories and Criteria. Version 3.1. Second edition. Gland, Switzerland and Cambridge, UK: IUCN. IV+ 32 pp. Available at http:// www.iucnredlist.org. Captured on 20 February 2016.

IUCN. 2012b. Guidelines for Application of IUCN Red List Criteria at Regional and National Levels. Version 4.0. Gland, Swizerland and Cambridge, UK: IUCN. III+41 pp. Available at http://www.iucnredlist.org. Captured on 20 February 2016.

IUCN. 2017. The IUCN Red List of Threatened Species. Version 2016-2. Available at http://www.iucnredlist.org. Captured on 15 August 2017.

Johansson, M., C. R. Primmer, and J. Merilä. 2007. Does habitat fragmentation reduce fitness and adaptability? A case study of the common frog (Rana temporaria). Molecular Ecology 16: 2693-2700.

MacKenzie, D. I., J. D. Nichols, J. E. Hines, M. G. Knutson, and A. B. Franklin. 2003. Estimating site occupancy, colonization, and local extinction when a species is detected imperfectly. Ecology 84: 2200-2207.

McDiarmid, R. W. and R. D. Worthington. 1970. Concerning the reproductive habits of tropical plethodontid salamanders. Herpetologica 26: 57-70.

Mendoza-Almeralla, C., P. Burrowes, and G. Parra-Olea. 2015. La quitridiomicosis en los anfibios de México: una revisión. Revista Mexicana de Biodiversidad 86: 238248.

Murrieta-Galindo, R., F. López-Barrera, A. GonzálezRomero, and G. Parra-Olea. 2013. Matrix and habitat quality in a montane cloud-forest landscape: amphibians in coffee plantations in central Veracruz, Mexico. Wildlife Research 40: 25-35.

Murrieta-Galindo, R., G. Parra-Olea, A. González-Romero, F. López-Barrera, and V. T. Vredenburg. 2014. Detection of Batrachochytrium dendrobatidis in amphibians 
inhabiting cloud forests and coffee agroecosystems in central Veracruz, Mexico. European Journal of Wildlife Research 60: 431-439.

Ogilvy, V., R. F. Preziosi, and A. L. Fidgett. 2012. A brighter future for frogs? The influence of carotenoids on the health, development and reproductive success of the redeye tree frog. Animal Conservation 15: 480-488.

Parra-Olea, G., S. M. Rovito, L. M. Valdelamar, G. Cruz, R. Murrieta-Galindo, and D. B. Wake. 2010. A new species of Pseudoeurycea from the cloud forest in Veracruz, México. Zootaxa 2725: 57-68.

Pavón-Vázquez, C. J., M. Arvizu-Meza, and U. O. GarcíaVázquez. 2015. Aquiloeurycea cephalica (Cope, 1865). Size and natural history. Mesoamerican Herpetology 2: $515-517$.

Phillips, S. J., R. P. Anderson, and R. E. Schapire. 2006. Maximum entropy modeling of species geographic distributions. Ecological Modelling 190: 231-259.

Rödel, M. -O. and R. Ernst. 2004. Measuring and monitoring amphibian diversity in tropical forests. I. An evaluation of methods with recommendations for standardization. Ecotropica 10: 1-14.

Rovito, S. M., G. Parra-Olea, E. Recuero, and D. B. Wake. 2015. Diversification and biogeographical history of Neotropical plethodontid salamanders. Zoological Journal of the Linnean Society 175: 167-188.

Sánchez, O., R. Medellín, A. Aldama, B. Goettsch, J. Soberón, and M. Tambutti. 2007. Método de Evaluación del Riesgo de Extinción de las Especies Silvestres en México (MER). SEMARNAT, INE, UNAM, CONABIO. Mexico. 170 pp.

Solano-Zavaleta, I., L. Canseco-Márquez, A. A. MendozaHernández, and L. F. Vázquez-Vega. 2013. Geographic Distribution: Pseudoeurycea cafetalera (Coffee Grove Salamander). Herpetological Review 44: 470-471.

Storfer, A., J. Cross, V. Rush, and J. Caruso. 1999. Adaptive coloration and gene flow as a constraint to local adaptation in the streamside salamander, Ambystoma barbouri. Evolution 53: 889-898.

Stuart, S. N., M. Hoffmann, J. S. Chanson, N. A. Cox, R. J. Berridge, P. Ramani, and B. E. Young (eds.). 2008. Threatened Amphibians of the World. Lynx Edicions, Barcelona, Spain; IUCN, Gland, Switzerland; and Conservation International Arlington, Virginia, USA. $758 \mathrm{pp}$.

Valdespino, C., A. I. Huerta-Peña, A. Pérez-Pacheco, and J. Rendón von Osten. 2015. Persistent organochlorine pesticides in two Hylidae species from the La Antigua watershed, Veracruz, Mexico. Bulletin of Environmental Contamination and Toxicology 94: 17-22.

Van Rooij, P., A. Martel, J. Nerz, S. Voitel, F. Van Immerseel, F. Haesebrouck, and F. Pasmans. 2011. Detection of Batrachochytrium dendrobatidis in Mexican bolitologlossine salamanders using an optimal sampling protocol. EcoHealth 8: 237-243.

Editor: Franco Andreone 